\title{
SAFETY OF PATIENTS AND MEDICAL STAFF IN CURRICULA AND TRAINING PROGRAMS FOR MEDICAL PROFESSIONALS IN UKRAINE
}

10.36740/WLek202010131

\author{
Oleksandr M. Naumenko ${ }^{1}$, Yurii M.Skaletsky², Viacheslav L. Didkovskyy' ${ }^{1}$, Mykhailo M. Rigann ${ }^{3}$, Oksana 0. Maluk ${ }^{4}$ \\ ${ }^{1}$ BOGOMOLETS NATIONAL MEDICAL UNIVERSITY, KYIV, UKRAINE \\ 2STATE INSTITUTION “0.M. MARZIEIEV INSTITUTE FOR PUBLIC HEALTH”NAMSU, KYIV, UKRAINE \\ ${ }^{3}$ CENTER FOR SPORTS TRAUMATOLOGY AND REHABILITATION MEDICINE OF THE NATIONAL UNIVERSITY OF PHYSICAL EDUCATION AND \\ SPORT OF UKRAINE, KYIV, UKRAINE \\ ${ }^{4}$ P.I.GAVROS KYIV MEDICAL COLLEGE, KYIV, UKRAINE
}

\begin{abstract}
The aim: The Canada and Poland experience in the educational field in the practical implementation of international practices for the prevention of patient safety incidents is significant, taking into consideration the effectiveness of health care models. We have to analyze the documents on the training of medical professionals in terms of safety as a first step in introducing into the domestic (Ukrainian) medical educational practice of existing international experience in teaching patient safety.

Materials and methods: The research was based on international documents on patient safety, thematic scientific publications, plans, and programs for the training of medical professionals in Ukraine. Bibliosemantic, systems analysis, mathematical (relative values) research methods were used in the study.

Conclusions: The analysis of thematic plans of separate disciplines in "Nursing" specialty has shown, that according to experts, questions of safety of patients should contain more than in $70 \%$ of subjects; on the topics of classes safety issues are provided in the range from $45.1 \%$ (basics of nursing) to $0.0 \%$ (anesthesiology and resuscitation); the actual content of educational and methodical materials was from $14.6 \%$ (basics of nursing) to $0.0 \%$ (anesthesiology and resuscitation).

The time allotted to study disciplines related to occupational safety and health of health workers (life safety, basics of bioethics and biosafety, as well as occupational safety in the industry) is six times higher than the hours of study of the discipline (medical law) related to patient safety in the Working Curriculum (second (master's) level of higher education in the field of knowledge 22 "health" specialty 222 "medicine"). As a result of the analysis of work programs of educational disciplines at all levels of medical specialists training, a sharp discrepancy in the new information support of the educational process was revealed in terms of patient safety.
\end{abstract}

KEY WORDS: Medical education, Patient Safety, Occupational Health

Wiad Lek. 2020;73(10):2265-2268

\section{INTRODUCTION}

The last two years have been marked by the emergence of a number of WHO resolutions [1] and declarations of the world medical community $[2,3]$ on patient safety, which once again confirm the urgency of the problem.

Summing up the experience of individual countries, regional and international organizations in creating a safe hospital environment for patients, we noted inconsistency in these documents in the prevention of defects in health care compared to the resources and efforts involved. There is an awareness of the need for more decisive concrete steps to minimize harm to patients in the provision of medical care. This one practical approach to preventing health care defects must be enshrined in the Fifth Global Ministerial Summit on Patient Safety 2020, which was unfortunately postponed due to the COVID-19 pandemic. The topic of this forum: "Less Harm Better care - from Resolution to Implementation."
It should also be added that the above documents confirm the importance of the education of medical staff in improving patient safety $[1,2]$. The experience of Canada is noteworthy in this respect, where a methodological basis has been formed for the preparation of patient safety prevention not only for doctors and nurses [4,5] but also for trainers who are implementing modern approaches in hospitals to prevent harm to patients.

It is also worth paying attention to the experience of neighboring Poland. There have recently appeared several thematic monographs $[6,7,8]$, thematic scientific and practical activities are carried out, implemented in the educational process of medical schools developed by the WHO on patient safety education [9]. Perhaps this is why inpatient mortality in Polish hospitals has declined in recent years.

Patient safety in most countries is not yet a traditional independent discipline; instead, it is the scattered knowl- 
Table 1. Results of the analysis of separate disciplines programs for higher medical (pharmaceutical) educational institutions of the I-III accreditation levels on a specialty 5.12010102 "Nursing", concerning safety of patients and medical personnel

\begin{tabular}{|c|c|c|c|c|c|}
\hline \multirow{2}{*}{ № } & \multirow{2}{*}{ Subjects } & \multicolumn{4}{|c|}{$\begin{array}{l}\text { Percentage of safety topics in the total amount of time for studying the } \\
\text { discipline (hours / \% of the whole time) }\end{array}$} \\
\hline & & According to experts & $\begin{array}{l}\text { On the topic of } \\
\text { the lesson }\end{array}$ & $\begin{array}{l}\text { By content } \\
\text { (actual) }\end{array}$ & Total \\
\hline 1. & Basics of nursing & $318 / 73,6$ & $194 / 45,1$ & $63 / 14,6$ & $432 / 100$ \\
\hline 2. & Nursing in surgery & $363 / 96$ & $128 / 33,9$ & $42 / 11,1$ & $378 / 100$ \\
\hline 3. & $\begin{array}{c}\text { Anesthesiology and } \\
\text { resuscitation }\end{array}$ & $71 / 87,7$ & $0 / 0$ & $0 / 0$ & $81 / 100$ \\
\hline
\end{tabular}

edge that is present in all areas of medicine and health care. That is, safety knowledge regarding the prevention of patient safety incidents in medical school teaching materials, as noted in [10], still remains more implicit than explicit. Although the WHO is increasingly emphasizing that patient safety is a medical discipline, the emergence of which is a response to the growing complexity of the process of providing medical services, which is accompanied by increasing harm to patients in medical institutions [11].

\section{THE AIM}

Based on the above, the purpose of our work is to analyze the documents on the training of medical professionals in terms of safety as a first step in introducing into the domestic (Ukrainian) medical educational practice of existing international experience in teaching patient safety.

\section{MATERIALS AND METHODS}

The research was based on international resolutions and declarations on patient safety. The experience of Canada and Poland in the practical implementation of global developments in the prevention of patient safety incidents in educational practice, thematic scientific publications, plans, and programs for the training of medical professionals in Ukraine were the materials of research, comparison, and analysis.

Research methods used in the study: bibliosemantic (metaanalysis), systems analysis, mathematical (relative values).

\section{REVIEW AND DISCUSSION}

Higher medical (pharmaceutical) educational institutions of I-III levels of accreditation in the specialty 5.12010102 "Nursing".

We have already tried to analyze the curricula and thematic training plans of medical college students on safety [12], but a detailed version of this analysis is provided for the first time.

Analysis of current programs of specific disciplines for higher medical (pharmaceutical) educational institutions of I-III levels of accreditation in the specialty 5.12010102 "Nursing", on the safety of patients and medical staff is given in table 1.
Analysis of the current thematic plans of specific disciplines for higher medical (pharmaceutical) educational institutions of I-III levels of accreditation in the specialty 5.12010102 "Nursing" on patient safety and medical staff showed:

- according to experts, safety issues should be included in more than $70 \%$ of the topics;

- on the topics of classes, safety issues are provided in the range from $45.1 \%$ (basics of nursing) to $0.0 \%$ (anesthesiology and resuscitation);

- actually, according to the content of educational and methodical materials, ranged from $14.6 \%$ (basics of nursing) to $0.0 \%$ (anesthesiology and resuscitation).

To confirm much more attention to occupational safety than patient safety in the training of future nurses, we present the results of the analysis of the thematic plan of the discipline "Nursing in Internal Medicine" for higher medical (pharmaceutical) educational institutions of I-III levels of accreditation in specialty 5.12010102 "Nursing".

9 out of 10 topics focus on the implementation of measures and means of personal occupational safety, anti-epidemic regime and occupational safety of nurses in providing medical care to patients, working with blood and other biological material, instrumental methods of examination, as well as safety measures while working with electric devices, the devices working under pressure, gas cylinders and so on. The problem of professional safety of medical staff is mentioned 12 times in topic 5. Concerning patient safety, some topics deal with the complexity of procedures and the administration of drugs and tactics of response to nurses, and patient safety issues limit by this only.

New sources of information on patient safety are absent in the list of the literature of the principal and additional to the above-mentioned thematic plans of disciplines.

Higher educational institutions for the training of specialists of the second (master's) level of higher education in the field of knowledge 22 "Health care" specialty 222 "Medicine". The budget of study time for the study of safety disciplines according to the Working Curriculum for 2019/2020 year for the training of specialists of the second (master's) level of higher education in the field of knowledge 22 "Health" specialty 222 "Medicine" [13] is presented in table 2.

The time allotted in the Work Curriculum for the study of disciplines related to occupational safety and health 
Table 2. Study time for safety disciplines according to the Working Curriculum for 2019/2020 year for training specialists of the second (master's) level of higher education in the field of knowledge 22"Health"specialty 222 "Medicine"

\begin{tabular}{|c|c|c|c|c|}
\hline \multirow{2}{*}{ № } & \multirow{2}{*}{$\begin{array}{l}\text { Name of the subjects related to } \\
\text { safety issues }\end{array}$} & \multicolumn{3}{|c|}{ Amount of hours } \\
\hline & & Total & Auditory & Students' self-training activities \\
\hline 1. & $\begin{array}{l}\text { Life safety, basics of bioethics and } \\
\text { biosafety }\end{array}$ & 90 & 40 & 50 \\
\hline 2. & Occupational Health & 90 & 30 & 60 \\
\hline 3. & Medical Law & 30 & 10 & 20 \\
\hline
\end{tabular}

(safety of life, basics of bioethics and biosafety, as well as occupational safety in the industry) is six times higher than the hours of study (medical law) concerning patient safety.

However, 1 hour of practical training and 2 hours of self-training activities (extramural work) is given to study topic 7, "Defects in medical care. Medical examination and quality control of medical care under the legislation of Ukraine ", which is actually devoted to patient safety, in accordance with the Program of the discipline "Medical Law "for students of higher medical educational institutions of III-IV levels of accreditation. by specialty - 7.12010001. Medical business; 7.12010002 Pediatrics; 7.12010004 Medical psychology [14]. That is $10 \%$ of the total study time of the discipline. However, as we can see, the topic of this lesson is somewhat broader, so the study of the actual issues of defects in medical care is given much less time. If we assume that the student, after completion of this discipline, should know the answers to 200 control questions, only 5 of which relate to the basic concepts of medical defects (or 2.5\%). Then 11.25 classroom classes minutes and 33, 75 minutes for self-study - a total of 45 minutes, or one academic hour are given to study the actual issues related to safety patients.

That is, in reality, the budget of study time allocated to the study of occupational safety and health of medical staff is 180 times higher than the limit of study time provided for the study of patient safety.

Again, there are no new sources on patient safety in the principal and auxiliary literature to the working curriculum in the discipline of "Medical Law".

Let's demonstrate the distribution of occupational safety and health issues and patient safety issues in the study of clinical disciplines on the example of the Working Curriculum for the discipline "General Surgery"]. Thus, of the 17 integrative final learning outcomes, the formation of which is facilitated by this discipline, two of them are related exclusively to the safety of staff and 3 to the safety of staff and patients together. That is a distinct advantage in favor of occupational safety and health of future doctors.

As for the skills of students that must be formed during the study of the discipline "General Surgery", 4 out of all 23 skills related to patient safety, and one to patient safety and occupational safety and health of medical staff. These issues are mainly related to the prevention of infections associated with medical care, prevention of bedsores, as well as prevention of complications from blood transfusions and anesthesia.
Of the 33 topics of classes provided by the program of the discipline "General Surgery", only four directly address the problems of patient safety, i.e., $12.1 \%$. It would be very optimistic to assume that out of this $12.1 \%$, about 10 th of the total time is devoted to safety issues. Thus, the net study time for patient safety in the study of "General Surgery" is allocated within $1 \%$ of the study time. The existence of defects prevention issues in the provision of medical care in other topics can only be guessed, i.e., these issues are present implicitly.

Of the 128 standardized theoretical questions for the final module control of the discipline, only 6 of them are related to patient safety, which is $4.7 \%$.

Neither the main nor the supporting literature for this working curriculum has new sources on patient safety.

Thus, the analysis of the current thematic plans of specific clinical disciplines for higher medical (pharmaceutical) educational institutions of I-III levels of accreditation in the specialty 5.12010102 "Nursing" shows a clear predominance in these plans of occupational safety of nurses compared to patient safety. At the same time, the actual amount of teaching aspects of patient safety is much lower than expected by experts.

Preliminary analysis of documents on the organization of the educational process in bulk medical educational institutions of III-IV levels of accreditation (master's degree) shows significant predominance the number of disciplines and the amount of study time for subjects related to occupational safety and health of doctors in comparison with subjects related to patient safety in the Working curriculum for training masters of higher education in the field of knowledge 22 "Health" for specialty 222 "Medicine". Issues of patient safety in working curricula in clinical disciplines (for example, the discipline of "General Surgery") training of medical professionals at the master's level prevail to some extent over the health and safety of future doctors, but most are presented implicitly.

Modern sources on the prevention of defects of medical care are absent in the recommended principal and additional literature of all analyzed programs of educational disciplines.

\section{CONCLUSIONS}

1. The issues of occupational safety of nurses clearly prevail over issues of patient safety in the current thematic plans of certain clinical disciplines for higher medical (pharmaceutical) educational institutions of I-III levels of accreditation in the specialty 5.12010102 "Nursing". At the same time, the actual amount of teaching aspects of patient safety is much lower than expected by experts. 
2. There is a significant predominance of the number of disciplines and the amount of study time for subjects related to occupational safety and health compared to patient safety disciplines in the Working Curriculum for the training of specialists of master's level of higher education in the field of knowledge 22 "Health" in the specialty 222 "Medicine".

3. Issues of patient safety in working curricula in clinical disciplines (on the example of the discipline "General Surgery") training of medical professionals at the master's level prevail to some extent over occupational safety, but most of them are presented in an implicit form.

4. There is an acute shortage of new information support of the educational process in terms of patient safety In all analyzed work programs of disciplines at all levels of training of medical specialists.

5. Only an in-depth analysis of the educational process in medical schools in terms of teaching patient safety will allow us to develop constructive recommendations for improving the training of medical personnel to prevent harm to patients in hospitals.

\section{REFERENCES}

1. Global'nye dejstvija po obespecheniju bezopasnosti pacientov. Rezoljucija 72 Vsemirnoj Assambleizdravoohranenija. WHA72.6.2019.8 p. URL:https://apps.who.int/gb/ebwha/pdf_files/WHA72/A72_R6-ru. pdf (Mode of Access: 03.06.2020). (In Russian).

2. Tokyo Declaration on Patient Safety. Third Global Ministerial Summit on Patient Safety, 14 April 2018, Tokyo, Japan. 2 p. URL: https://www. mhlw.go.jp/file/06-Seisakujouhou-10800000-Iseikyoku/0000204005. pdf (Mode of Access : 2.06.2020).

3. Jeddah Declaration on Patient Safety. 2019. URL: https://www. bundesgesundheitsministerium.de/fileadmin/Dateien/3_ Downloads/P/Patientensicherheit/PSS_2019/Patientensicherheit_ Erklaerung_Dschidda_2019.pdf (Mode of Access : 2.06.2020).

4. The Safety Competencies. Enhancing Patient Safety Across the Health Professions First Edition. Canadian Patient Safety. Ottawa. 2009/ 46 p. URL : Institute.https://www.patientsafetyinstitute.ca/ en/toolsResources/safetyCompetencies/Documents/Safety $\% 20$ Competencies.pdf (Mode of Access : 2.06.2020).

5. Report on the integration of the safety competencies framework into health professions education programs in Canada. Canadian Patient Safety Institute. Ottawa. 2016. URL : https://www.patientsafetyinstitute. ca/en/toolsResources/Integration-of-Safety-Competencies-Framework/ Documents/Report\%20on\%20the\%20Integration\%20of\%20the\%20 Safety\%20Competencies\%20Framework.pdf (Mode of Access : 2.06.2020).

6. Anna Borysewicz. Błąd medyczny i nieskuteczna zgoda na leczenie odpowiedzialność indywidualna i w spółce partnerskiej wzory pism. 2017. 134 s. URL: https://www.medicon.pl/blad-medyczny-inieskuteczna-zgoda-na-leczenie-odpowiedzialnosc-indywidualna-i-wspolce-partnerskiej-wzory-pism/15620/ (Mode of Access : 2.06.2020).

7. Marcin Mikos. Bezpieczeństwo pacjenta. 2017. 285 s. URL : https:// www.acusmed.pl/sklep/ksiazki-dla-fizjoterapeutow/bezpieczenstwopacjenta-marcin-mikos (Mode of Access: 2.06.2020).

8. Monika Sadowska.Zapobieganiebłędom medycznym w praktyce. 2018.282 s.URL:https://www.profinfo.pl/sklep/zapobieganie-bledom-medycznymw-praktyce,100360.html?_ga =2.79982164.2127132695.1583918304686314245.1583918304 (Mode of Access: 2.06.2020).
9. Bezpieczeństwo Pacjenta. Przewodnik i Wskazówki dla Kadry Dydaktycznej opracowane przez WHO: wydanie przeznaczone dla przedstawicieli różnych zawodów medycznych. Polskie Towarzystwo Medycyny Ubezpieczeniowej, 2017. 299 . URL:https://apps.who. int/iris/bitstream/handle/10665/44641/9789241501958-pol. pdf?sequence $=35$ (Mode of Access: 2.06.2020).

10. Patient safety in health care professional educational curricula: examining the learning experience, 2009. http://www.birmingham. ac.uk/Documents/college-mds/haps/projects/cfhep/psrp/finalreports/ PS030PSRPReportFINAL0609.pdf.

11. Patient Safety. (2019, September 13). Retrieved July 06, 2020, from https://www.who.int/news-room/fact-sheets/detail/patient-safety

12. Maljuk 0.0. Vikladannja pitan'bezpeki pacientiv studentam medichnogo koledzhu. Materiali mizhnarodnoï naukovo-praktichnoï konferenciï, $\mathrm{m}$. Dnipro, 6-7 chervnja 2017 roku .Za zagal'noju redakcieju akad. NAMN Ukraïni Serdjuka A. M. ta chlena-korespondenta NAMN Ukraïni Percevoï T. 0., 2017; 65-67. (In Ukrainian).

13. Robochij navchal'nij plan na 2019/2020 n. r. z pidgotovki fahivciv drugogo (magisters'kogo) rivnja vishhoï osviti galuzi znan'22 «Ohorona zdorov'ja» special'nist' 222 «Medicina». Dodatok 1 do nakazu MOZ Ukraïni № 392 vid 26.04.2019 p. (In Ukrainian).

14. Mihajlichenko B.V. Medichne pravo. Programa navchal'noï disciplini dlja studentiv vishhih medichnih navchal'nih zakladiv III-IV rivniv akreditaciï. Special'nosti - 7.12010001. Likuval'na sprava; 7.12010002 Pediatrija; 7.12010004 Medichna psihologija. B.V. Mihajlichenko, I.Ju. Hmil', M.S. Sergienko. K.: NMU imeni 0.0. Bogomol'cja. 2019. 33. (In Ukrainian).

15. Robocha navchal' na programa $z$ disciplini "Zagal' na hirurgija» pidgotovki fahivciv drugogo (magisters'kogo) rivnja galuz' znan' 22 «Ohorona zdorov'ja» special' nosti 222 «Medicina». O.I. Dronov, I.0. Koval's'ka, I.L. Nastashenko ta insh. NMU imeni 0.0. Bogomol'cja. K.: NMU imeni 0.0. Bogomol'cja. 2019. 39. (In Ukrainian).

\section{ORCID and contributionship:}

Oleksandr M. Naumenko: 0000-0002-9001-7580

Yurii M. Skaletsky: 0000-0002-2263-953X

Viacheslav L. Didkovskyy: 0000-0001-7581-3530 D,F

Mykhailo M. Rigan: 0000-0003-1244-9801 B,E

Oksana O. Maluk: 0000-0003-4337-7759

\section{Conflict of interest:}

The Authors declare no conflict of interest

\section{CORRESPONDING AUTHOR Oleksandr M. Naumenko}

Bogomolets National Medical University, Kyiv, Ukraine

e-mail:md.omelchuk@ukr.net

Received: 16.06 .2020

Accepted: 02.09 .2020

A - Work concept and design, B - Data collection and analysis, C - Responsibility for statistical analysis, D - Writing the article, $\mathbf{E}$ - Critical review, $\mathbf{F}$ - Final approval of the article 